\title{
Pengaruh Terpaan Media terhadap Kesadaran Mahasiswa tentang Protokol Kesehatan Covid-19 3M (Memakai Masker, Mencuci Tangan, Menjaga Jarak)
}

\author{
Nadya Kinasih Alkautsar *, Dian Widya Putri \\ Fakultas Ilmu Komunikasi, Universitas Islam Bandung, Indonesia. \\ *kinasihnadya@gmail.com, dianwidyaputrisy@gmail.com
}

\begin{abstract}
Covid-19 case first discovered in Wuhan, China, on December 2019. In Indonesia, Covid19 case first discovered on March 2nd 2020. Since the emerges of the case, Indonesia's Ministry of Health created a law to prevent the spread of the disease, which called Protokol Kesehatan Covid-19. One of the attempt to implement the law, Indonesian goverment create a rule called $3 \mathrm{M}$, which is an abbreviation of Memakai Masker, Mencuci Tangan, Menjaga Jarak (Wearing Mask, Wash Hands, Social Dinstancing). That rule is spread by various mass media. The purpose of this research, is to find out the effectfrom the spread of the news regarding 3M (Memakai Masker, Mencuci Tangan, Menjaga Jarak) rule, towards the consciousness of the citizen to applying those rule in everyday activity, with the sample of research are 94 student of Communication Science Faculty in Bandung Islamic University. Using the theory of Uses\&Effects by Sven Windahl with quantitative research methode using a simple linear regression analysis. The results of this research shows : There's an effect from the frequency of media's news exposure towards the student's conciousness in implementation of 3M rules, there's an effect from the attention media's news exposure towards the student's conciousness in implementation of 3M rules, there's an effect from the duration of media's news exposure towards the student's conciousness in implementation of $3 \mathrm{M}$ rules, there's an effect from the media's news exposure towards the student's conciousness in implementation of $3 \mathrm{M}$ rules.
\end{abstract}

Keywords: Protokol Kesehatan Covid-19, 3M, Consciousness, Uses and Effects Theory.

Abstrak. Kasus penyakit Covid-19 pertama kali ditemukan di Wuhan, Cina pada bulan Desember 2019. Lalu menyebar hingga ke Indonesia sejak tanggal 2 Maret 2020. Semenjak muncul kasus tersebut, Kementerian Kesehatan mengeluarkan aturan untuk mencegah penyebaran penyakit Covid19 yang dinamakan Protokol Kesehatan Covid-19. Salah satu upaya untuk melaksanakan aturan tersebut, pemerintah mengeluarkan aturan yang disebut 3M yang merupakan singkatan dari Memakai Masker, Mencuci Tangan, dan Menjaga Jarak. Aturan tersebut, disebarkan di berbagai media massa, baik online maupun tradisional. Penelitian ini, bertujuan untuk menganalisis pengaruh dari penyebaran berita mengenai Protokol Kesehatan Covid-19 3M (Memakai Masker, Mencuci Tangan, dan Menjaga Jarak) pada media online Kompas.com, terhadap kesadaran masyarakat dalam menerapkan aturan tersebut, dengan sampel penelitian adalah 94 mahasiswa dari Fakultas Ilmu Komunikasi Universitas Islam Bandung. Penelitian ini, menggunakan Teori Uses \& Effects dari Sven Windahl dengan menggunakan metode penelitian kuantitatif dengan analisis regresi linear sederhana. Hasil dari penelitian ini menunjukkan : Terdapat pengaruh dari frekuensi terpaan media terhadap kesadaran mahasiswa dalam menerapkan aturan $3 \mathrm{M}$, terdapat pengaruh dari atensi terpaan media terhadap kesadaran mahasiswa dalam menerapkan aturan $3 \mathrm{M}$, terdapat pengaruh dari durasi terpaan media terhadap kesadaran dalam menerapkan aturan 3M, terdapat pengaruh dari terpaan media terhadap kesadaran mahasiswa dalam menerapkan aturan 3M.

Kata Kunci: Protokol Kesehatan Covid-19, 3M, Kesadaran, Teori Uses and Effects. 


\section{A. Pendahuluan}

Kasus penyakit Covid-19 pertama kali muncul di Wuhan, China. Lalu penyakit tersebut juga ikut menyebar ke berbagai negara, termasuk ke Indonesia, tepatnya pada 2 Maret 2020. Penyakit ini menyerang sistem pernapasan manusia, yang diawali dengan infeksi melalui droplet dari orang yang terkena virus SARS CoV-2, lalu virus tersebut memasuki hidung dan tenggorokan.

Dikabarkan juga bahwa penyakit Covid-19 ini akan menjadi penyakit endemi, yaitu kemunculan penyakit yang menjadi umum berada pada populasi atau suatu wilayah geografis. (Arnani, Mela. "WHO Sebut Covid-19 Bisa Jadi Penyakit Endemik, Ini Bedanya dengan Epidemi, dan Pandemi”. Kompas.com. Senin, 1 Maret 2021) Sehingga pemerintah di Indonesia menyatakan dibutuhkan adanya 'new normal', yaitu keadaan dimana masyarakat akan hidup berdampingan dengan penyakit ini sehingga diterapkan aturan-aturan baru dalam keseharian. (WH, Fajar. "Mengenal Konsep New Normal”. Indonesia.go.id. Minggu, 31 Mei 2020) Maka pemerintah membentuk sebuah aturan untuk mencegah penyebaran penyakit Covid-19. Aturan tersebut dinamakan Protokol Kesehatan Covid-19, dimana salah satu nya dalam mewujudkan aturan tersebut, dibentuk sebuah aturan bernama 3M yang merupakan singkatan dari Memakai Masker, Mencuci Tangan, dan Menjaga Jarak , aturan ini disebarkan di berbagai media massa, baik online maupun tradisional.

Menurut Direktur WHO, Takeshi Kasai, menyatakan usia 20-40 menjadi pendorong penyebar Covid-19. Takeshi beralasan, karena mereka aktif berkegiatan di tengah masyarakat, sehingga berisiko tertular di perjalanan atau di tempat bekerja. Tetapi dikarenakan kondisi fisik yang bugar, sebagian besar orang pada kelompok usia ini bisa tidak memiliki atau minim gejala. (Anwar, Firdaus. "Alasan Orang Usia 20-40 Tahun Disebut Jadi Pendorong Pandemi Corona" detikhealth, Rabu, 19 Agustus 2020).

Sehingga, dikarenakan sangat penting bagi masyarakat yang berusia $20-40$ tahun untuk memiliki kesadaran dalam menerapkan aturan 3M (Memakai Masker, Mencuci Tangan, Menjaga Jarak) ini dalam rangka mencegah penyebaran penyakit Covid-19, maka penelitian ini ditujukan untuk masyarakat yang berada dalam rentang usia 20 lebih yaitu mahasiswa Fakultas Ilmu Komunikasi Universitas Islam Bandung.

Berdasarkan data yang ditemukan juga oleh peneliti dari perusahaan konsultasi komunikasi Maverick Indonesia pada saat konferensi daring "Where Gen Y and Z Get Their News From" tanggal 15 Desember 2020, ditemukan bahwa generasi muda yang berumur 18-32 tahun, kebanyakan memakai media massa portal berita online sebagai sumber berita utamanya.

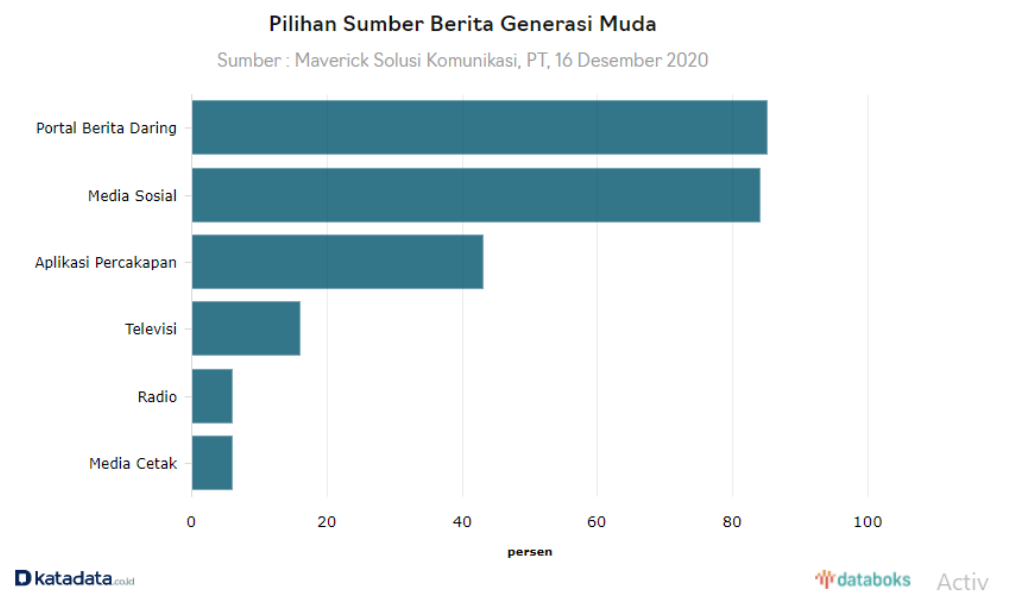

Gambar 1. Statistik Sumber Berita Pilihan Generasi Muda

Berdasarkan survei yang telah dilakukan oleh Maverick Indonesia ini juga, didapatkan portal berita online Kompas.com menempati posisi pertama sebagai portal berita online pilihan masyarakat muda yang berumur 18-32 tahun. (Kasih, Ayunda. "Kompas.com Jadi Portal Berita Online Pilihan Generasi Y dan Z "Kompas.com, Selasa, 15 Desember 2020). 
Pada penelitian ini, untuk mengetahui pengaruh dari media terhadap mahasiswa, digunakan teori terpaan media yang diukur melalui 3 aspek (Elvinaro, 2007: 15), yaitu frekuensi, yang merupakan seberapa sering individu mengonsumsi suatu pesan dari media, lalu atensi yaitu seberapa dalam individu memperhatikan pesan dari sebuah media, dan durasi merupakan seberapa lama individu mengonsumsi pesan dari media.

Sedangkan kesadaran menurut menurut Hasibuan (2012:193) adalah sikap sukarela manusia untuk mematuhi berbagai aturan dan kesadaran untuk bertanggung jawab dalam melakukan tugas-tugasnya. Sehingga kesadaran diukur menggunakan model Tricomponent sikap menurut (Schiffman, \& Kanuk, 2010:249). Aspek-aspek tersebut antara lain kognitif, afektif, dan konatif. Kognitif merupakan pengetahuan serta pandangan yang muncul dimana nantinya akan membentuk suatu keyakinan, afektif merupakan emosi atau perasaan penerima terhadap suatu pesan, dan konatif merupakan perilaku melalui sebuah cara yang spesifik, yang berhubungan dengan objek sikap.

Dengan berdasar pada teori Uses\&Effect yang dikemukakan oleh Sven Windahl, dimana menurut teori ini, efek atau pengaruh didapatkan dari penggunaan suatu media, dan penggunaan tersebut ditentukan oleh faktor kebutuhan, karakteristik, harapan, pandangan, serta akses terhadap media.

Dan efek yang didapat dibagi menjadi 3 yaitu, efek, yang merupakan hasil dari proses konsumsi pesan media, dan pemakaian media dianggap selaku aspek perantara saja. Lalu konsekuensi, yang merupakan hasil dari penggunaan media, yang dapat mengurangi aktivitas lain, juga dapat memunculkan konsekuensi psikologis seperti ketergantungan terhadap media tertentu. Dan Consseffect, yaitu hasil yang didapat baik karena isi pesan juga penggunaan media. Keduanya memberikan hasil yang sama sehingga disebut consseffects yang merupakan gabungan dari konsekuensi dan efek. (Rohim, 2009: 189).

Berdasarkan latar belakang yang telah diuraikan, maka perumusan masalah dalam penelitian ini sebagai berikut: "Apakah terdapat pengaruh terpaan media online Kompas.com mengenai pemberitaan Protokol Kesehatan Covid-19 terhadap kesadaran mahasiswa Fakultas Ilmu Komunikasi Universitas Islam Bandung untuk menerapkan aturan 3M (Memakai Masker, Mencuci Tangan, Menjaga Jarak)?". Selanjutnya, tujuan dalam penelitian ini diuraikan dalam pokok-pokok sbb.

1. Untuk mengetahui pengaruh dari frekuensi terpaan media online kompas.com mengenai pemberitaan protokol kesehatan covid-19 terhadap kesadaran mahasiswa fakultas ilmu komunikasi universitas islam bandung untuk menerapkan aturan 3m (memakai masker, mencuci tangan, menjaga jarak)

2. Untuk mengetahui pengaruh dari atensi terpaan media online Kompas.com mengenai pemberitaan Protokol Kesehatan Covid-19 terhadap kesadaran mahasiswa Fakultas Ilmu Komunikasi Universitas Islam Bandung untuk menerapkan aturan 3M (Memakai Masker, Mencuci Tangan, Menjaga Jarak)

3. Untuk mengetahui pengaruh dari durasi terpaan media online Kompas.com mengenai pemberitaan Protokol Kesehatan Covid-19 terhadap kesadaran mahasiswa Fakultas Ilmu Komunikasi Universitas Islam Bandung untuk menerapkan aturan 3M (Memakai Masker, Mencuci Tangan, Menjaga Jarak)

4. Untuk mengetahui pengaruh dari terpaan media online Kompas.com mengenai pemberitaan Protokol Kesehatan Covid-19 terhadap kesadaran mahasiswa Fakultas Ilmu Komunikasi Universitas Islam Bandung untuk menerapkan aturan 3M (Memakai Masker, Mencuci Tangan, Menjaga Jarak)

\section{B. Metodologi Penelitian}

Metode penelitian yang digunakan pada penelitian ini yaitu metode kuantitatif, metode yang tujuannya mendapat jawaban dari penelitian yang berhubungan dengan data angka ataupun statistik (Wahidmurni, 2017:1)

Dengan paradigma positivisme, dimana sesuai dari tujuan dari penelitian ini, yaitu mengetahui pengaruh antarvariabel maka paradigma maka yang dipakai adalah positivisme karena menurut (Sugiyono 2017 :45), penelitian kuantitatif berdasarkan kepada filsafat 
positivisme, yaitu filsafat yang mempunyai pandangan bahwa sebuah realitas, gelaja, atau fenomena bisa diklasifikasikan, konkrit, teramati, dapat diukur, relatif tetap, dan ada hubungan sebab-akibat, dengan menggunakan teknik analisis regresi linear sederhana. Dan teknik analisis regresi linear sederhana, dalam (Wijayanto, 2008: 1), digunakan untuk mengukur pengaruh antara variabel bebas terhadap variabel terikat.

Populasi yang digunakan disini yaitu mahasiswa di Fakultas Ilmu Komunikasi Universitas Islam Bandung dari angkatan 2017, 2018, 2019, dan 2020 yang berjumlah 1,511 mahasiswa, untuk mengambil sampel dari populasi penelitian, teknik pengambilan sampel yang digunakan adalah Random Sampling, dengan menggunakan rumus slovin dengan tingkat kepercayaan $90 \%$ dan nilai $e=10 \%$, didapatkan sampel dari populasi sebagai berikut:

$\mathrm{n}=\frac{N}{1+N e^{2}}$

$\mathrm{n}=\frac{1511}{1+1511(10 \%)^{2}}=\frac{1511}{1+1511(0.01)}=\frac{1511}{1+15,11}=\frac{1511}{16.11}=94$

Maka didapatkan jumlah sampel diperlukan untuk mewakili populasi sebanyak 1.511 mahasiswa di Fakultas Ilmu Komunikasi Universitas Islam Bandung, adalah sebanyak 94 mahasiswa.

Teknik pengumpulan data yang digunakan yaitu kuesioner dengan menggunakan Google Form, dikarenakan penelitian ini dilakukan dalam kondisi pandemi sehingga penyebaran kuesioner dilakukan secara online agar mencegah penyebaran penyakit Covid-19. Menggunakan skala ordinal likert, untuk menilai jawaban, yang terdiri dari pilihan jawaban sangat setuju bernilai 5 , setuju bernilai 4 , ragu-ragu bernilai 3 , tidak setuju bernilai 2 , dan sangat tidak setuju bernilai 1 .

\section{Hasil Penelitian dan Pembahasan}

\section{Pengaruh Frekuensi Terpaan Media Terhadap Kesadaran Mahasiswa}

Tabel 1. Pengaruh Frekuensi Terpaan Media(X) terhadap Kesadaran Mahasiswa (Y)

Coefficients $^{a}$

\begin{tabular}{|rr|r|r|r|r|r|}
\hline \multicolumn{2}{|l|}{ Model } & \multicolumn{2}{|c|}{$\begin{array}{c}\text { Unstandardized } \\
\text { Coefficients }\end{array}$} & \multicolumn{1}{|c|}{$\begin{array}{c}\text { Standardized } \\
\text { Coefficients }\end{array}$} & \multirow{2}{*}{ Sig. } \\
\cline { 2 - 5 } & \multicolumn{1}{|c|}{$\mathrm{B}$} & Std. Error & \multicolumn{1}{c|}{ Beta } & & \\
\hline 1 & (Constant) & 32,628 & 3,015 & & 10,823 &, 000 \\
& Frekuensi &, 734 &, 214 &, 336 & 3,421 &, 001 \\
\hline
\end{tabular}

a. Dependent Variable: Kesadaran

Berdasarkan tabel di atas, dapat dilihat bahwa hasil uji analisis regresi linear sederhana yang telah dilakukan peneliti dapat dibuat persamaan regresi sebagai berikut:

$$
\mathrm{Y}=32,628+0,734 \mathrm{X}
$$

Berdasarkan persamaan tersebut, dapat diartikan bahwa setiap penambahan $1 \%$ tingkat frekuensi terpaan media online Kompas.com mengenai pemberitaan Protokol Kesehatan Covid19 (X1) maka kesadaran mahasiswa Fakultas Ilmu Komunikasi Universitas Islam Bandung untuk melaksanakan aturan 3M (Memakai Masker, Mencuci Tangan, dan Menjaga Jarak) (Y) akan meningkat sebesar 0,734 .

Sedangkan pada tabel Sig. didapatkan bahwa nilai signifikansi yang didapat adalah 0,001 yang berarti nilai tersebut lebih kecil dari 0,05 sehingga dapat disimpulkan bahwa variabel frekuensi terpaan media online Kompas.com mengenai pemberitaan Protokol Kesehatan Covid19 (X1) berpengaruh kepada variabel kesadaran mahasiswa Fakultas Ilmu Komunikasi Universitas Islam Bandung untuk melaksanakan aturan 3M (Memakai Masker, Mencuci Tangan, dan Menjaga Jarak) (Y). 
Tabel 2. Tabel R Square Frekuensi

Model Summary

\begin{tabular}{|l|r|r|r|r|}
\hline Model & \multicolumn{1}{|c|}{$\mathrm{R}$} & $\mathrm{R}$ Square & \multicolumn{1}{|c|}{$\begin{array}{c}\text { Adjusted R } \\
\text { Square }\end{array}$} & $\begin{array}{r}\text { Std. Error of } \\
\text { the Estimate }\end{array}$ \\
\hline 1 &, $336^{\mathrm{a}}$ &, 113 &, 103 & 4,895 \\
\hline
\end{tabular}

a. Predictors: (Constant), Frekuensi

Berdasarkan hasil tabel diatas juga, didapatkan bahwa nilai R Square adalah 0,113. Ini berarti, aspek frekuensi terpaan media online Kompas.com berpengaruh senilai 11,3\% terhadap kesadaran mahasiswa Fakultas Ilmu Komunikasi Universitas Islam Bandung untuk melaksanakan aturan 3M (Memakai Masker, Mencuci Tangan, dan Menjaga Jarak) sementara sisanya adalah faktor-faktor lain yang tidak dibahas pada penelitian ini. Berarti juga, nilai pengaruhnya cukup rendah.

Maka, pada aspek frekuensi didapatkan nilai t hitung sebesar 3,421 dikarenakan nilai tersebut lebih besar dari nilai t tabel $(\mathrm{t} 0,025 ; 92)$ yaitu 1,989 maka terdapat pengaruh dan bernilai positif dari frekuensi terpaan media online Kompas.com mengenai berita Protokol Kesehatan Covid-19 terhadap kesadaran mahasiswa Fakultas Ilmu Komunikasi Universitas Islam Bandung untuk menerapkan aturan 3M (Memakai Masker, Mencuci Tangan, dan Menjaga Jarak), dengan persentase pengaruh yaitu $11,3 \%$.

Dari hasil tersebut, sehingga dapat disimpulkan bahwa $\mathrm{H}_{0}$ ditolak dan $\mathrm{H}_{1}$ diterima, atau terdapat pengaruh dari frekuensi terpaan media online Kompas.com mengenai pemberitaan Protokol Kesehatan Covid-19 (X1) kepada variabel kesadaran mahasiswa Fakultas Ilmu Komunikasi Universitas Islam Bandung untuk melaksanakan aturan 3M (Memakai Masker, Mencuci Tangan, dan Menjaga Jarak) (Y).

\section{Pengaruh Atensi Terpaan Media Terhadap Kesadaran Mahasiswa}

Tabel 3. Pengaruh Atensi Terpaan Media(X) terhadap Kesadaran Mahasiswa (Y)

\section{Coefficients $^{a}$}

\begin{tabular}{|c|c|c|c|c|c|}
\hline \multirow[t]{2}{*}{ Model } & \multicolumn{2}{|c|}{ Unstandardized Coefficients } & \multirow{2}{*}{$\begin{array}{c}\begin{array}{c}\text { Standardized } \\
\text { Coefficients }\end{array} \\
\text { Beta }\end{array}$} & \multirow[t]{2}{*}{$\mathrm{t}$} & \multirow[t]{2}{*}{ Sig. } \\
\hline & $B$ & Std. Error & & & \\
\hline (Constant) & 31,322 & 2,584 & & 12,121 & 000 \\
\hline Atensi & 1,058 & ,234 & ,426 & 4,521 & 000 \\
\hline
\end{tabular}

a. Dependent Variable: Kesadaran

Berdasarkan tabel di atas, dapat dilihat bahwa dari hasil uji analisis regresi linear yang telah dilakukan peneliti dapat dibuat persamaan regresi sebagai berikut:

$$
\mathrm{Y}=31,322+1,058 \mathrm{X}
$$

Berdasarkan persamaan tersebut, dapat diartikan bahwa setiap penambahan $1 \%$ tingkat atensi terpaan media online Kompas.com mengenai pemberitaan Protokol Kesehatan Covid-19 (X2) maka kesadaran mahasiswa Fakultas Ilmu Komunikasi Universitas Islam Bandung untuk melaksanakan aturan 3M (Memakai Masker, Mencuci Tangan, dan Menjaga Jarak) (Y) akan meningkat sebesar 1,058 .

Sedangkan pada tabel Sig. didapatkan bahwa nilai signifikansi yang didapat adalah 0,000 yang berarti nilai tersebut lebih kecil dari 0,05 sehingga dapat disimpulkan bahwa atensi terpaan media online Kompas.com mengenai pemberitaan Protokol Kesehatan Covid-19 (X2) berpengaruh kepada variabel kesadaran mahasiswa Fakultas Ilmu Komunikasi Universitas Islam Bandung untuk melaksanakan aturan 3M (Memakai Masker, Mencuci Tangan, dan Menjaga Jarak) (Y). 
Tabel 4. Tabel R Square Atensi

Model Summary

\begin{tabular}{|l|r|r|r|r|}
\hline Model & $R$ & $R$ Square & \multicolumn{1}{|c|}{$\begin{array}{l}\text { Adjusted } R \\
\text { Square }\end{array}$} & $\begin{array}{l}\text { Std. Error of the } \\
\text { Estimate }\end{array}$ \\
\hline 1 &, $426^{\mathrm{a}}$ &, 182 &, 173 & 4,701 \\
\hline
\end{tabular}

a. Predictors: (Constant), Atensi

Berdasarkan hasil tabel diatas juga, didapatkan bahwa nilai R Square adalah 0,182. Ini berarti, aspek atensi terpaan media online Kompas.com berpengaruh senilai 18,2\% terhadap kesadaran mahasiswa Fakultas Ilmu Komunikasi Universitas Islam Bandung untuk melaksanakan aturan 3M (Memakai Masker, Mencuci Tangan, dan Menjaga Jarak) sementara sisanya adalah faktor-faktor lain yang tidak dibahas pada penelitian ini. Berarti juga, nilai pengaruhnya cukup rendah.

Maka pada aspek atensi didapatkan nilai t hitung sebesar 4,521 dikarenakan nilai tersebut lebih besar dari nilai $\mathrm{t}$ tabel $(\mathrm{t} 0,025$; 92) yaitu 1,989 maka terdapat pengaruh dan bernilai positif dari atensi terpaan media online Kompas.com mengenai berita Protokol Kesehatan Covid-19 terhadap kesadaran mahasiswa Fakultas Ilmu Komunikasi Universitas Islam Bandung untuk menerapkan aturan 3M (Memakai Masker, Mencuci Tangan, dan Menjaga Jarak), dengan persentase pengaruh yaitu $18,2 \%$.

Dari hasil tersebut, sehingga dapat disimpulkan bahwa $\mathrm{H} 0$ ditolak dan $\mathrm{H} 1$ diterima, atau terdapat pengaruh dari atensi terpaan media online Kompas.com mengenai pemberitaan Protokol Kesehatan Covid-19 (X2) kepada variabel kesadaran mahasiswa Fakultas Ilmu Komunikasi Universitas Islam Bandung untuk melaksanakan aturan 3M (Memakai Masker, Mencuci Tangan, dan Menjaga Jarak) (Y).

\section{Pengaruh Durasi Terpaan Media Terhadap Kesadaran Mahasiswa}

Tabel 5. Pengaruh Durasi Terpaan Media(X) terhadap Kesadaran Mahasiswa (Y)

Coefficients $^{\mathrm{a}}$

\begin{tabular}{|rl|r|r|r|r|r|}
\hline \multicolumn{2}{|l|}{ Model } & \multicolumn{2}{|c|}{ Unstandardized Coefficients } & $\begin{array}{c}\text { Standardized } \\
\text { Coefficients }\end{array}$ & \multicolumn{1}{c|}{ Sig. } \\
\cline { 3 - 5 } & & \multicolumn{1}{|c|}{$\mathrm{B}$} & Std. Error & \multicolumn{1}{|c|}{ Beta } & & \\
\hline \multirow{2}{*}{1} & (Constant) & 32,127 & 2,382 & & 13,488 &, 000 \\
& Durasi & 1,508 &, 330 &, 431 & 4,575 &, 000 \\
\hline
\end{tabular}

a. Dependent Variable: Kesadaran

Berdasarkan tabel di atas, dapat dilihat bahwa dari hasil uji analisis regresi linear yang dilakukan peneliti dapat dibuat persamaan regresi sebagai berikut:

$$
\mathrm{Y}=32,127+1,058 \mathrm{X}
$$

Berdasarkan persamaan tersebut, dapat diartikan bahwa setiap penambahan $1 \%$ tingkat durasi terpaan media online Kompas.com mengenai pemberitaan Protokol Kesehatan Covid-19 (X3) maka kesadaran mahasiswa Fakultas Ilmu Komunikasi Universitas Islam Bandung untuk melaksanakan aturan 3M (Memakai Masker, Mencuci Tangan, dan Menjaga Jarak) (Y) akan meningkat sebesar 1,508.

Sedangkan pada tabel Sig. didapatkan bahwa nilai signifikansi yang didapat adalah 0,000 yang berarti nilai tersebut lebih kecil dari 0,05 sehingga dapat disimpulkan bahwa durasi terpaan media online Kompas.com mengenai pemberitaan Protokol Kesehatan Covid-19 (X3) berpengaruh kepada variabel kesadaran mahasiswa Fakultas Ilmu Komunikasi Universitas Islam Bandung untuk melaksanakan aturan 3M (Memakai Masker, Mencuci Tangan, dan Menjaga Jarak) (Y). 
Tabel 6. Tabel R Square Durasi

Model Summary

\begin{tabular}{|l|r|r|r|r|}
\hline Model & $\mathrm{R}$ & R Square & \multicolumn{1}{|c|}{$\begin{array}{l}\text { Adjusted R } \\
\text { Square }\end{array}$} & $\begin{array}{l}\text { Std. Error of the } \\
\text { Estimate }\end{array}$ \\
\hline 1 &, $431^{\mathrm{a}}$ &, 185 &, 177 & 4,691 \\
\hline
\end{tabular}

a. Predictors: (Constant), Durasi

Berdasarkan hasil tabel diatas juga, didapatkan bahwa nilai R Square adalah 0,185. Ini berarti, aspek durasi terpaan media online Kompas.com berpengaruh senilai 18,5\% terhadap kesadaran mahasiswa Fakultas Ilmu Komunikasi Universitas Islam Bandung untuk melaksanakan aturan 3M (Memakai Masker, Mencuci Tangan, dan Menjaga Jarak) sementara sisanya adalah faktor-faktor lain yang tidak dibahas pada penelitian ini. Berarti juga, nilai pengaruhnya cukup rendah.

Maka pada aspek durasi didapatkan nilai t hitung sebesar 4,575 dikarenakan nilai tersebut lebih besar dari nilai t tabel $(\mathrm{t} 0,025 ; 92)$ yaitu 1,989 maka disimpulkan bahwa terdapat pengaruh dan bernilai positif (Ghozali 2016:97) dari durasi terpaan media online Kompas.com mengenai berita Protokol Kesehatan Covid-19 terhadap kesadaran mahasiswa Fakultas Ilmu Komunikasi Universitas Islam Bandung untuk menerapkan aturan 3M (Memakai Masker, Mencuci Tangan, dan Menjaga Jarak), dengan persentase pengaruh yaitu 18,5\%.

Dari hasil tersebut, sehingga dapat disimpulkan bahwa $\mathrm{H}_{0}$ ditolak dan $\mathrm{H}_{1}$ diterima, atau terdapat pengaruh dari durasi terpaan media online Kompas.com mengenai pemberitaan Protokol Kesehatan Covid-19 (X3) kepada variabel kesadaran mahasiswa Fakultas Ilmu Komunikasi Universitas Islam Bandung untuk melaksanakan aturan 3M (Memakai Masker, Mencuci Tangan, dan Menjaga Jarak) (Y).

\section{Kesimpulan}

Berdasarkan pembahasan dalam penelitian ini, peneliti menyimpulkan beberapa hasil penelitian sebagai berikut:

1. Frekuensi atau semakin seringnya mahasiswa diterpa oleh media Kompas.com dengan berita mengenai Protokol Kesehatan Covid-19, mampu mempengaruhi kesadaran mahasiswa Fakultas Ilmu Komunikasi Universitas Islam Bandung untuk menerapkan aturan 3M (Memakai Masker, Mencuci Tangan, dan Menjaga Jarak) dalam keseharian. Dengan persentase pengaruhnya $11,3 \%$.

2. Dari atensi terpaan media atau perhatian mahasiswa dalam membaca berita dari media online Kompas.com mengenai pemberitaan Protokol Kesehatan Covid-19, dimana karena perhatian ini mahasiswa memahami berita yang dibaca, akhirnya dapat berpengaruh terhadap kesadaran mahasiswa Fakultas Ilmu Komunikasi Universitas Islam Bandung untuk melaksanakan aturan 3M (Memakai Masker, Mencuci Tangan, dan Menjaga Jarak) dengan persentase pengaruh senilai $18,2 \%$.

3. Dari durasi terpaan media pun didapatkan pengaruh terhadap kesadaran mahasiswa Fakultas Ilmu Komunikasi Universitas Islam Bandung untuk melaksanakan aturan 3M (Memakai Masker, Mencuci Tangan, dan Menjaga Jarak), dimana berarti dikarenakan terpaan media Kompas.com dalam memberitakan mengenai Protokol Kesehatan Covid19 selama kurang lebih 3 bulan, dapat menimbulkan pengaruh dengan persentase $18,5 \%$.

\section{Acknowledge}

Terimakasih kepada Ibu Dian Widya atas bimbingannya sehingga peneliti bisa menyelesaikan penelitian ini. 
142 | Nadya Kinasih Alkautsar, et al.

\section{Daftar Pustaka}

[1] Ardianto, Elvinaro dkk. 2007. Komunikasi Massa Suatu Pengantar. Bandung: Simbiosa Rekatama Media. h. 15

[2] Hasibuan, Malayu. 2012. Manajemen Sumber Daya Manusia. Jakarta: PT Bumi Aksara. hal.193

[3] Schiffman, Leon G., Kanuk, Leslie Lazar, Wisenblit, Joseph. 2010. Consumer Behavior, 10thEdition, New Jersey: Pearson Education, Inc. h.249

[4] Sugiyono. 2017. Metode Penelitian Kuantitatif, Kualitatif, dan R\&D. Bandung : Alfabeta, CV.

[5] Wahidmurni. 2017. Pemaparan Metode Penelitian Kuantitatif. Journal review. hal. 1-7.

[6] Wijayanto, A. (2008). Analisis Regresi Linear Sederhana. Semarang: Universitas Diponegoro. 